\title{
Reaction of Soybean Cyst Nematode Resistant Plant Introductions to Root-Knot and Reniform Nematodes
}

\author{
Jeong-Dong Lee ${ }^{1}$, Hyun-Jee Kim ${ }^{1}$, Robert T. Robbins ${ }^{2}$, James A. Wrather ${ }^{3}$, Jason Bond ${ }^{4}$, Henry T. Nguyen ${ }^{5}$, \\ J. Grover Shannon ${ }^{3} *$ \\ ${ }^{1}$ School of Applied Biosciences, Kyungpook National University, Daegu 41566, Korea \\ ${ }^{2}$ Department of Plant Pathology, Nematology Laboratory, University of Arkansas, Fayetteville, AR 72701, USA \\ ${ }^{3}$ Division of Plant Sciences, University of Missouri-Delta Research Center, Portageville, MO 63873, USA \\ ${ }^{4}$ Department of Plant, Soil Science and Agriculture System, University of Southern Illinois, Carbondale 62901, USA \\ ${ }^{5}$ Division of Plant Sciences, University of Missouri, Columbia, MO 65211, USA
}

\begin{abstract}
Soybean cyst [SCN, Heterodera glycines Ichinohe], southern root-knot [RKN, Meloidogyne incognita (Kofoid and White) Chitwood] and reniform nematodes [RN, Rotylenchlus reniformis (Linford and Oliveria)] are common plant-parasitic nematode species in southern US fields. Each nematode individually or collectively causes significant economic losses to field grown soybean. A subset of 120 soybean plant introductions (PIs) selected from the USDA Soybean Germplasm Collection have been shown to be resistant to one or more SCN populations (HG Types); however, many of these PIs have not been screened for resistance to either RKN or RN. The objective of this research was to evaluate these germplasm accessions for resistance to RKN and RN. The evaluation for RKN resistance was conducted in RKN infested field plantings after potatoes near Charleston, MO in 2006 and 2007 . The evaluation for RN resistance was performed in a greenhouse at Fayetteville, AR, in 2007. Out of these accessions, 64 PIs were identified with high or moderate resistance to RKN. Of these 64 lines, 24 accessions showed good resistance to both RKN and RN. These new sources of resistance to multiple nematodes will be valuable materials for soybean breeding programs to develop new resistant cultivars that can overcome yield losses caused by one or more of these nematode species.
\end{abstract}

Keywords Soybean, Cyst nematode, Root-knot nematode, Reniform nematode

\section{INTRODUCTION}

Soybean [Glycine max (L.) Merr.] cyst nematode (SCN, Heterodera glycines Ichinohe), southern root-knot nematode [RKN, Meloidogyne incognita (Kofoid and White) Chitwood], and reniform nematode (RN, Rotylenchlus reniformis Linford and Oliveria) are significant pathogens in southern U.S. soybean fields (Wrather and Koenning 2009). They cause approximately 157 billion U.S. dollars in damage worldwide (Klink et al. 2009).

SCN generally has caused more yield reduction than any other soybean disease. Estimated yield losses was 3.3 million tons in 2009 in 28 U.S. states (Wrather and Koenning 2010). RKN often occurs in soybean fields, but to a lesser extent than SCN (Wrather et al. 2003) with losses estimated at 1.9 million tons over 28 U.S. states in 2009 (Wrather and Koenning 2010). If RKN interacts with other disease pathogens, damage is greater than would occur with RKN alone (Goswami and Agrawal 1978). Another nematode species, RN causes root decay, poor growth, reduced pod set, and significant yield reduction in susceptible soybean cultivars (Niblack et al. 2004).

Nematicide applications were once a cost-effective manner and widely used as an option to manage nematode infestation (Niblack et al. 2004). However, growers were reluctant to use chemical control due to high costs, environmental toxicity and human health concerns. Thus, breeding for new soybean cultivars with resistance to one or more species is a cost effective and environmentally friendly measure to reduce soybean yield losses to nematodes.

Received November 5, 2015; Revised November 10, 2015; Accepted November 12, 2015; Published November 30, 2015

*Comesponding author J. Grover Shannon, shannong@missouri.edu, Tel: +1-573-379-4036, Fax:+1-573-379-5875 
The use of SCN-resistant soybean cultivars, such as Forrest, prevented approximately \$401 million in soybean yield losses at a cost of only about $\$ 1$ million for the variety development (Bradley and Duffy 1982). However, continuous cultivation of SCN resistant soybean cultivars may accelerate selection pressure for other nematode species, particularly RKN and RN that also damage soybeans (Schmitt and Barker 1988). Stetina et al. (1997) reported that RKN resistant soybean likely results in an increase of RN over time. Therefore, cultivars with resistance to multiple nematode species are essential in preventing losses from these pests which can occur in the same field. Several sources of resistance to RKN have been identified in soybean, which were being used in soybean breeding programs to develop soybean germplasm lines resistant to both SCN and RKN (Boerma et al. 1991; Luzzi et al. 1997). SCN-resistant soybean genotypes derived from cultivars Custer, Hartwig, Peking, PI437654, and PI 90763 are potentially also resistant to RN (Robbins et al. 1994a, 1994b; Davis et al. 1996).

Soybean plant introductions (PIs) selected from the USDA Soybean Germplasm Collection were screened in several studies and it was reported that about 120 accessions have shown to be resistant to one or more SCN populations or HG types (Shannon et al. 2004). However, many of these PI lines have not been screened for resistance to either RKN or RN. The purpose of this study was to collectively evaluate this subset of SCN resistant accessions for resistance to RKN and RN to identify sources resistant to all three nematode species.

\section{MATERIALS AND METHODS}

\section{Soybean cyst nematode resistant genotypes}

A total of 120 soybean PIs in maturity groups (MGs) I to VII from the USDA Soybean Germplasm Collection (Shannon et al. 2004), previously identified as having SCN resistance to one or more SCN HG Types were evaluated to both RKN and RN to determine which of these SCN sources carried resistant to one or both of these species.

\section{Root-knot nematode evaluation}

One hundred twenty soybean PIs were evaluated for resistance to RKN in highly infested fields following potatoes near Charleston, MO on a Dundee sandy loam (Aeric Ochraqualfs). Levels of RKN at each site were not determined but, sandy soils following spring potatoes in Missouri often have high levels of RKN after harvest in late June and July. Ten seeds of each soybean accession were planted in hill plots spaced $61 \mathrm{~cm}$ apart in rows $76 \mathrm{~cm}$ wide at two sites in 2006 and one site in 2007. Planting dates were June 26, 2006 and June 30, 2007. The experimental design was a randomized complete block design (RCBD) with two replications. Six weeks after planting, soybean plants in each hill were dug with a shovel to expose root systems for determining reaction to RKN. Reaction to RKN damage was measured by root-knot galling and scored using a 1-5 scale (Luzzi et al. 1997) where $1=$ no galls and $5=$ very severe galling. A score of 3 or less was considered as resistance reaction. Cultivar 5601T (Pantalone et al. 2003) was used as the resistant check, and cultivar Anand (Anand et al. 2001) was used as the susceptible check.

\section{Renifom nematode evaluation}

After RKN evaluations, 64 PI lines that showed consistent resistance to $\mathrm{RKN}$ with galling scores $\leq 3$ were phenotyped for resistance to $\mathrm{RN}$ in a greenhouse facility of the University of Arkansas, Fayetteville, AR, in 2007. Seeds were germinated in vermiculite. Seedlings at the cotyledon stage or VC growth stage (Fehr and Caviness 1977) were then transplanted into 10-cm-diameter clay pots (one seedling per pot) containing $500 \mathrm{~cm}^{3}$ of pasteurized fine sandy loam soil (ca. 91\% sand, 5\% silt, $4 \%$ clay, and $<1 \%$ organic matter). Each pot was inoculated into three, 2.5 cm-deep holes made in the soil with approximately 2,000 vermiform RN using an auto pipette. The experimental design was an RCBD with ten replications. For resistant checks, cultivars Anand (Robbins et al. 2006; Stetina et al. 2014) and Forrest (Williams et al. 1981; Stetina et al. 2014) and for susceptible checks, cultivars Braxton (Robbins and Rakes 1996) and Hutcheson (Buss et al. 1988) were included. A reproductive index (RI \%) was estimated to evaluate the response of each pot of $\mathrm{RN}$ using the following 
formula (Robbins et al. 1999), RI (\%)=(Number of eggs + vermiform nematodes at test termination/Initial infestation level) $\times 100$.

\section{Statistical analysis}

All statistical analyses were conducted using PROC GLM scripts of SAS version 8 program (SAS Institute 2004). The differences among mean values were and tested by Duncan's Multiple Range Test at $P \leq 0.05$. The statistical analysis and tests were performed for only the 64 selected accessions that showed resistance to RKN.

\section{RESULTS}

\section{Root-knot nematode resistance}

The RKN and RN reaction of SCN resistant germplasm accessions for resistance to RKN are presented in Table 1. Among the 120 SCN resistant PI lines studied, 64 accessions (Table 1) showed galling scores of 3.0 or less over two years of evaluation at three sites. Their means were not significantly different $(P=0.95)$ and not different from the moderately resistant RKN check 5601T which had a score of 3.0. The root galling score of 64 accessions ranged from 1.3 to 3.0 with an average score of 2.3, indicating that these accessions were resistant or moderately resistant to RKN based on their performance relative to the resistant check, cv. 5601T. Among these, three accessions, PI404198B, PI438342, and PI532444A showed the lowest root galling scores with an average score of 1.3, indicating these three accessions possessed the highest level of resistance to RKN. According to a previous report (Shannon et al. 2004) PI404198B was reported to be highly resistant to SCN races 1, 3, and 5 (HG Types 2.5.7, 0 , and 2.5.7, respectively) and moderately resistant to race 14 (HG Type 1.3.5.6.7), while PI438342 was resistant to SCN race 5 (HG Type 2.5.7) and PI532444A was moderately resistant to SCN races 2, 3, 5, and 14 (HG Types 1.2.5.7, 0, 2.5.7, and 1.3.5.6.7) as shown in Table 1.

\section{Renifom nematode resistance}

There was a significant difference $(P<0.01)$ among the 64 RKN resistance PI accessions for reaction to RN as shown in Table 1. The average reproductive index (RI \%) for RN was $13.1 \%$. A minimum RI of $0.1 \%$ was estimated for PI507471 and a maximum RI of $45.8 \%$ was estimated for PI438496B. Among the four check genotypes, cv. Anand had the lowest RI of $0.8 \%$ and cv. Braxton had the highest index of 308.1\%. Nine accessions, PI404198A, PI438498, PI467327, PI468915, PI494182, PI507470, PI507471, PI507476, and PI567516C showed similar or less RI (\%) than a resistant check, cv. Anand. Thus, these nine accessions had high levels of resistance to RN. Among these accessions, PI404198A showed an RI of 0.5\% for RN and a score of 2.8 for RKN. PI408198A had been reported to be resistant to SCN races 1, 2, 3, and 5 (HG Types 2.5.7, 1.2.5.7, 0, and 2.5.7, respectively). PI438489B with resistance to SCN races 1, 2, 3, 5, and 14 (HG Types 2.5.7, 1.2.5.7, 0, 2.5.7, and 1.3.5.6.7, respectively) showed RI of $0.9 \%$ for RN and a score of 2.2 for RKN. PI467327 was reported to be resistant to SCN races 1 and 3 (HG Types 2.5.7 and 0, respectively) with RI of $0.2 \%$ for $\mathrm{RN}$ and a RKN score of 2.8. A wild soybean (G. soja) accession PI468915 with SCN resistance to races 1, 3 and 5 (HG Types 2.5.7, 0, and 2.5.7) showed $0.4 \%$ of RI for RN, and a score of 2.3 for RKN. PI494182 with resistance to races 1, 3, and 5 (HG Types 2.5.7, 0, 2.5.7, respectively) and moderately resistant to race 2 (HG Type 1.2.5.7) of SCN, had an RI of $0.4 \%$ for RN and a score of 2.8 for RKN. PI507470 with resistance to SCN race 1 (HG Type 2.5.7) and moderate resistant to race 5 (HG Type 2.5.7) had an RI of $0.7 \%$ for RN and a score of 2.7 for RKN. PI507471 with resistance to races 2 and 5 and moderately resistant to race 1 and 14 had a very low RI of $0.1 \%$ for RN and a score of 2.7 score for RKN. PI507476 with resistance to races 3 and 5 and moderate resistant to race 1 of SCN had an RI of $0.5 \%$ for RN, and a score of 2.2 score for RKN. PI567516C with SCN resistance to races 1 and 3 and moderate resistance to race 2 in addition to resistance to the Hartwig SCN HG type had an RI of $0.8 \%$ for RN, and a RKN score of 2.2. The resistant check cultivar, Forrest with resistance to races 1 (HG type 2.5.7) and 3 (HG type 0) and resistance to RKN (Hartwig and Epps 1973) showed an RI of 5.0\% for RN. Among the 64 remaining RKN resistant accessions, 15 accessions, PI089772, PI303652, PI404198B, PI417091, PI424137B, PI437690, PI438342, PI438489B, PI468903, 
Table 1. Response of SCN resistance sources (Shannon et al. 2004) to root-knot nematode (RKN) and reniform nematode (RN).

\begin{tabular}{|c|c|c|c|c|c|c|c|c|}
\hline \multirow[b]{3}{*}{ Genotype } & \multirow{3}{*}{$\begin{array}{c}\text { Maturity } \\
\text { group }\end{array}$} & \multicolumn{7}{|c|}{ Nematode reaction } \\
\hline & & \multicolumn{5}{|c|}{$\mathrm{SCN}^{2)}$} & \multirow{2}{*}{$\begin{array}{r}\mathrm{RKN}^{\mathrm{y}} \\
(1-5)\end{array}$} & \multirow{2}{*}{$\begin{array}{c}\mathrm{RN}^{\mathrm{x})} \\
\mathrm{RI}(\%)\end{array}$} \\
\hline & & $\begin{array}{c}\text { Race } 1 \\
\text { (HG Type } \\
\text { 2.5.7) }\end{array}$ & $\begin{array}{c}\text { Race } 2 \\
\text { (HG Type } \\
1.2 .5 .7 \text { ) }\end{array}$ & $\begin{array}{c}\text { Race } 3 \\
\text { (HG } \\
\text { Type 0) }\end{array}$ & $\begin{array}{c}\text { Race } 5 \\
\text { (HG Type } \\
2.5 .7 \text { ) }\end{array}$ & $\begin{array}{c}\text { Race } 14 \\
\text { (HG Type } \\
\text { 1.3.5.6.7) }\end{array}$ & & \\
\hline Peking & IV & $\mathrm{R}$ & & $\mathrm{R}$ & $\mathrm{R}$ & MR & $1.5 \mathrm{a}$ & $5.3 \mathrm{p}-\mathrm{z}$ \\
\hline PI079693 & III & MR & & MR & MR & MR & $2.0 \mathrm{a}$ & 23.8 e-m \\
\hline PI088788 & III & & & $\mathrm{R}$ & & $\mathrm{R}$ & $2.0 \mathrm{a}$ & $17.8 \mathrm{f}-\mathrm{p}$ \\
\hline PI089008 & II & & & MR & MR & MR & $2.3 \mathrm{a}$ & $19.1 \mathrm{f}-\mathrm{p}$ \\
\hline PI089014 & II & MS & & MS & MS & MS & 3.0 a & $15.0 \mathrm{~h}-\mathrm{t}$ \\
\hline PI089772 & IV & $\mathrm{R}$ & $\mathrm{R}$ & $\mathrm{R}$ & $\mathrm{R}$ & MR & $2.5 \mathrm{a}$ & $3.4 \mathrm{r}-\mathrm{z}$ \\
\hline PI090763 & IV & $\mathrm{R}$ & $\mathrm{R}$ & $\mathrm{R}$ & $\mathrm{R}$ & & $1.5 \mathrm{a}$ & $6.3 \mathrm{p}-\mathrm{z}$ \\
\hline PI209332 & IV & & & $\mathrm{R}$ & $\mathrm{R}$ & $\mathrm{R}$ & $2.0 \mathrm{a}$ & $31.5 \mathrm{~b}-\mathrm{g}$ \\
\hline PI303652 & $\mathrm{V}$ & $\mathrm{R}$ & & $\mathrm{R}$ & $\mathrm{R}$ & MR & $2.2 \mathrm{a}$ & $1.8 \mathrm{~s}-\mathrm{Z}$ \\
\hline PI398680 & IV & & & MR & & & $2.7 \mathrm{a}$ & 38.4 b-e \\
\hline PI398682 & IV & & & MR & & & $2.2 \mathrm{a}$ & $27.6 \mathrm{~d}-\mathrm{i}$ \\
\hline PI404198A & IV & $\mathrm{R}$ & $\mathrm{R}$ & $\mathrm{R}$ & $\mathrm{R}$ & & $2.8 \mathrm{a}$ & $0.5 \mathrm{xyz}$ \\
\hline PI404198B & IV & $\mathrm{R}$ & & $\mathrm{R}$ & $\mathrm{R}$ & MR & $1.3 \mathrm{a}$ & $1.1 \mathrm{u}-\mathrm{z}$ \\
\hline PI407729 & IV & MR & & & & & $2.2 \mathrm{a}$ & $8.7 \mathrm{n}-\mathrm{z}$ \\
\hline PI416762 & II & MR & & $\mathrm{R}$ & $\mathrm{R}$ & $\mathrm{R}$ & $1.7 \mathrm{a}$ & 13.6 h-y \\
\hline PI417091 & II & MR & & $\mathrm{R}$ & $\mathrm{R}$ & $\mathrm{R}$ & $2.0 \mathrm{a}$ & $4.4 \mathrm{q}-\mathrm{z}$ \\
\hline PI417094 & III & & & MR & MR & MR & $2.5 \mathrm{a}$ & $14.5 \mathrm{~h}-\mathrm{u}$ \\
\hline PI424137B & IV & & & & MR & MR & $3.0 \mathrm{a}$ & $1.3 \mathrm{t}-\mathrm{z}$ \\
\hline PI437090 & 0 & & & & MS & MS & $2.5 \mathrm{a}$ & $12.1 \mathrm{j}-\mathrm{z}$ \\
\hline PI437655 & III & $\mathrm{R}$ & & $\mathrm{R}$ & $\mathrm{R}$ & MR & $3.0 \mathrm{a}$ & $12.3 \mathrm{j}-\mathrm{z}$ \\
\hline PI437690 & III & $\mathrm{R}$ & $\mathrm{R}$ & $\mathrm{R}$ & $\mathrm{R}$ & MR & $2.8 \mathrm{a}$ & $2.4 \mathrm{r}-\mathrm{z}$ \\
\hline PI437725 & IV & $\mathrm{R}$ & & $\mathrm{R}$ & $\mathrm{R}$ & & $2.7 \mathrm{a}$ & 17.8 f-p \\
\hline PI437770 & III & & & $\mathrm{R}$ & & MR & $2.8 \mathrm{a}$ & $25.3 \mathrm{~d}-\mathrm{k}$ \\
\hline PI437908 & II & & & MR & & & $2.5 \mathrm{a}$ & 16.3 g-r \\
\hline PI438183 & II & & & MR & & & $2.8 \mathrm{a}$ & $9.6 \mathrm{~m}-\mathrm{z}$ \\
\hline PI438342 & VI & & & & $\mathrm{R}$ & & $1.3 \mathrm{a}$ & $1.1 \mathrm{u}-\mathrm{z}$ \\
\hline PI438489B & IV & $\mathrm{R}$ & $\mathrm{R}$ & $\mathrm{R}$ & $\mathrm{R}$ & $\mathrm{R}$ & $2.2 \mathrm{a}$ & $0.9 \mathrm{u}-\mathrm{z}$ \\
\hline PI438496B & III & MR & & $\mathrm{R}$ & & & $2.7 \mathrm{a}$ & $45.8 \mathrm{~b}$ \\
\hline PI438498 & IV & $\mathrm{R}$ & MR & $\mathrm{R}$ & $\mathrm{R}$ & & $2.3 \mathrm{a}$ & 0.5 xyz \\
\hline PI438503A & II & & & $\mathrm{R}$ & MR & $\mathrm{R}$ & $2.0 \mathrm{a}$ & $14.5 \mathrm{~h}-\mathrm{u}$ \\
\hline PI458175B & IV & & & & MR & & $2.0 \mathrm{a}$ & $6.6 \mathrm{o-z}$ \\
\hline PI458199 & IV & & MR & & MR & & $2.0 \mathrm{a}$ & $14.4 \mathrm{~h}-\mathrm{w}$ \\
\hline PI458519A & II & MR & MR & MR & MR & MR & $2.3 \mathrm{a}$ & $19.0 \mathrm{f}-\mathrm{p}$ \\
\hline PI458520 & II & & & $\mathrm{R}$ & $\mathrm{R}$ & MR & $1.5 \mathrm{a}$ & 20.9 f-o \\
\hline PI461509 & I & & MR & $\mathrm{R}$ & MR & MR & $1.8 \mathrm{a}$ & $7.4 \mathrm{n}-\mathrm{z}$ \\
\hline
\end{tabular}

Means followed by the same letter are not significantly different at $P=0.05$ by Duncan's Multiple Range Test.

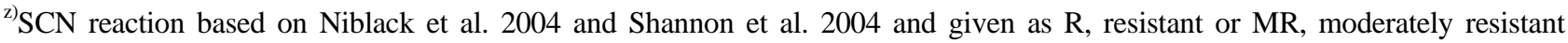
to races 1 (HG Type 2.5.7), 2 (HG Type 1.2.5.7), 3 (HG Type 0), 5 (HG Type 2.5.7), and 14 (HG Type 1.3.5.6.7).

${ }^{\mathrm{y})} \mathrm{RKN}$ data: mean value averaged data from three locations with two reps across 2006 and 2007. Scored from 1=no root galls and 5=severe root galling, a score of 3.0 or less is considered showing some resistance.

${ }^{\mathrm{x})} \mathrm{RN}$ reaction is reproductive index (RI), calculated by dividing the average number of eggs + vermiform nematodes on each PI at test termination by the number of eggs and vermiform nematodes on cultivars Anand and Forrest (resistant checks). 
Table 1. Continued.

\begin{tabular}{|c|c|c|c|c|c|c|c|c|}
\hline \multirow[b]{3}{*}{ Genotype } & \multirow{3}{*}{$\begin{array}{c}\text { Maturity } \\
\text { group }\end{array}$} & \multicolumn{7}{|c|}{ Nematode reaction } \\
\hline & & \multicolumn{5}{|c|}{$\mathrm{SCN}^{\mathrm{z})}$} & \multirow{2}{*}{$\begin{array}{r}\mathrm{RKN}^{\mathrm{y})} \\
(1-5)\end{array}$} & \multirow{2}{*}{$\begin{array}{l}\mathrm{RN}^{\mathrm{x})} \\
\mathrm{RI}(\%)\end{array}$} \\
\hline & & $\begin{array}{c}\text { Race } 1 \\
\text { (HG Type } \\
\text { 2.5.7) }\end{array}$ & $\begin{array}{c}\text { Race } 2 \\
\text { (HG Type } \\
1.2 .5 .7)\end{array}$ & $\begin{array}{c}\text { Race } 3 \\
\text { (HG } \\
\text { Type 0) }\end{array}$ & $\begin{array}{c}\text { Race } 5 \\
\text { (HG Type } \\
\text { 2.5.7) }\end{array}$ & $\begin{array}{c}\text { Race } 14 \\
\text { (HG Type } \\
\text { 1.3.5.6.7) }\end{array}$ & & \\
\hline PI467312 & II & & MR & $\mathrm{R}$ & $\mathrm{R}$ & $\mathrm{R}$ & $2.7 \mathrm{a}$ & $7.7 \mathrm{n}-\mathrm{z}$ \\
\hline PI467327 & II & & $\mathrm{R}$ & & $\mathrm{R}$ & & $2.8 \mathrm{a}$ & $0.2 \mathrm{z}$ \\
\hline PI468903 & II & MR & $\mathrm{R}$ & $\mathrm{R}$ & $\mathrm{R}$ & & $3.0 \mathrm{a}$ & $1.5 \mathrm{t}-\mathrm{z}$ \\
\hline PI468915 & II & $\mathrm{R}$ & MR & $\mathrm{R}$ & $\mathrm{R}$ & & $2.3 \mathrm{a}$ & $0.4 \mathrm{yz}$ \\
\hline PI475810 & II & & & & MR & MR & $2.0 \mathrm{a}$ & 45.4 bc \\
\hline PI490769 & III & & MR & MR & MR & MR & $2.7 \mathrm{a}$ & $24.7 \mathrm{~d}-\mathrm{l}$ \\
\hline PI494182 & 0 & $\mathrm{R}$ & MR & $\mathrm{R}$ & $\mathrm{R}$ & & $2.8 \mathrm{a}$ & $0.4 \mathrm{yz}$ \\
\hline PI495017C & IV & & MR & $\mathrm{R}$ & & MR & $2.2 \mathrm{a}$ & $3.2 \mathrm{r}-\mathrm{z}$ \\
\hline PI506862 & IV & & MR & & $\mathrm{R}$ & & $2.0 \mathrm{a}$ & $4.0 \mathrm{q}-\mathrm{z}$ \\
\hline PI507354 & I & $\mathrm{R}$ & MR & $\mathrm{R}$ & $\mathrm{R}$ & & $1.5 \mathrm{a}$ & $1.0 \mathrm{u}-\mathrm{z}$ \\
\hline PI507422 & VI & $\mathrm{R}$ & & $\mathrm{R}$ & & & $2.0 \mathrm{a}$ & $2.3 \mathrm{~s}-\mathrm{z}$ \\
\hline PI507423 & VI & MR & & $\mathrm{R}$ & & & $1.8 \mathrm{a}$ & $3.9 \mathrm{q}-\mathrm{z}$ \\
\hline PI507470 & VI & $\mathrm{R}$ & & & MR & & $2.7 \mathrm{a}$ & $0.7 \mathrm{xyz}$ \\
\hline PI507471 & III & MR & $\mathrm{R}$ & & $\mathrm{R}$ & MR & $2.7 \mathrm{a}$ & $0.1 \mathrm{z}$ \\
\hline PI507476 & VI & MR & & $\mathrm{R}$ & $\mathrm{R}$ & & $2.2 \mathrm{a}$ & $0.5 \mathrm{xyz}$ \\
\hline PI509095 & VII & MR & & $\mathrm{R}$ & MR & & $2.7 \mathrm{a}$ & $1.4 \mathrm{t}-\mathrm{z}$ \\
\hline PI532434 & II & & MR & MR & & MR & $3.0 \mathrm{a}$ & $40.6 \mathrm{bcd}$ \\
\hline PI532444A & $\mathrm{I}$ & & MR & MR & MR & MR & $1.3 \mathrm{a}$ & $21.3 \mathrm{f}-\mathrm{n}$ \\
\hline PI548316 & III & & & MR & & & $2.2 \mathrm{a}$ & $13.9 \mathrm{~h}-\mathrm{x}$ \\
\hline PI567285 & IV & & & $\mathrm{R}$ & & & $2.0 \mathrm{a}$ & 16.2 g-r \\
\hline PI567415A & IV & MR & & & MR & $\mathrm{R}$ & $2.7 \mathrm{a}$ & $11.1 \mathrm{k}-\mathrm{z}$ \\
\hline PI567421 & IV & & & & & $\mathrm{R}$ & $3.0 \mathrm{a}$ & $15.8 \mathrm{~h}-\mathrm{s}$ \\
\hline PI567492 & IV & & & & & $\mathrm{R}$ & $3.0 \mathrm{a}$ & 15.9 g-s \\
\hline PI567510A & III & & & & & $\mathrm{R}$ & $2.8 \mathrm{a}$ & 33.6 b-f \\
\hline PI567512B & II & & & & & $\mathrm{R}$ & $1.5 \mathrm{a}$ & $13.3 \mathrm{i}-\mathrm{z}$ \\
\hline PI567516C & IV & $\mathrm{R}$ & MR & $\mathrm{R}$ & & & $2.2 \mathrm{a}$ & $0.8 \mathrm{w}-\mathrm{z}$ \\
\hline PI567535A & IV & & & & & $\mathrm{R}$ & $1.7 \mathrm{a}$ & 40.1 b-e \\
\hline PI567581 & IV & & & & & $\mathrm{R}$ & $2.5 \mathrm{a}$ & $27.7 c-i$ \\
\hline PI567636 & IV & & & $\mathrm{R}$ & & & $2.3 \mathrm{a}$ & 28.1 b-h \\
\hline $5601 \mathrm{~T}$ & Check & & & & & & $3.0 \mathrm{a}$ & \\
\hline Anand & Check & & & & & & $4.0 \mathrm{a}$ & $0.8 \mathrm{w}-\mathrm{z}$ \\
\hline Forrest & Check & & & & & & & $5.0 \mathrm{q}-\mathrm{z}$ \\
\hline Hutcheson & Check & & & & & & & $25.8 \mathrm{~d}-\mathrm{j}$ \\
\hline Braxton & Check & & & & & & & $308.1 \mathrm{a}$ \\
\hline$P$ & & & & & & & 0.95 & $<0.01$ \\
\hline
\end{tabular}

Means followed by the same letter are not significantly different at $P=0.05$ by Duncan's Multiple Range Test.

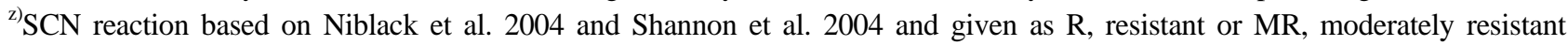
to races 1 (HG Type 2.5.7), 2 (HG Type 1.2.5.7), 3 (HG Type 0), 5 (HG Type 2.5.7), and 14 (HG Type 1.3.5.6.7).

${ }^{\mathrm{y})} \mathrm{RKN}$ data: mean value averaged data from three locations with two reps across 2006 and 2007. Scored from 1=no root galls and 5=severe root galling, a score of 3.0 or less is considered showing some resistance.

${ }^{\mathrm{x})} \mathrm{RN}$ reaction is reproductive index (RI), calculated by dividing the average number of eggs + vermiform nematodes on each PI at test termination by the number of eggs and vermiform nematodes on cultivars Anand and Forrest (resistant checks). 
PI495017C, PI506862, PI507354, PI507422, PI507423, and PI50909 showed an RI for RN equal to or less than the Forrest but higher than the Anand indicating that these 15 accessions are resistant to RN.

\section{DISCUSSION}

Among 120 cultivated soybean germplasm accessions from the USDA Soybean Germplasm Collection, previously reported to be resistant to single or multiple SCN HG Types, 64 accessions showed resistant to RKN (Table 1). Greg et al. (2008) reported that cultivars JGL934014XRJ and JGL937014XRJ were resistant to SCN, but were highly susceptible to RKN. About half of the SCN resistant accessions evaluated showed susceptiblity to RKN. Out of 64 accessions showing different levels of resistance to both SCN and RKN, 24 accessions showed high resistant to RN. Therefore, these 24 accessions have resistance to SCN, $\mathrm{RKN}$, and RN.

Efforts have been made to develop new soybean varieties resistant to SCN, RKN, and RN. For SCN resistance, the cultivar Hartwig was utilized as a resistance source in different soybean breeding programs to develop superior soybean cultivar with broad resistance to SCN (Anand 1992; Faghihi et al. 1995). Vierling et al. (1996) identified and mapped a QTL region on Chromosome (Chr. 11) for resistance to SCN race 3 (HG Type 0) in a mapping population derived from cv. Hartwig that explained $91 \%$ of the total phenotypic variation for resistance to SCN. This QTL region showed the highest effect ever reported for a single SCN resistance QTL. Genetic studies reported five major genes, Rhg1 to Rhg5, underlying resistance to different SCN races (Rao-Arelli 1994). The QTL conferring a high level of resistance to SCN in many sources was mapped to the regions containing rhg1 and Rhg4 on Chrs. 8 and 18, respectively (Concibido et al. 2004; Wu et al. 2009; Vuong et al. 2011). Multiple resistance to SCN races 1, 2, 3, 5, 14, and LY1 QTL were identified and mapped on Chrs. 10 and 18 from PI567516C (Vuong et al. 2010). Recently, Jiao et al. (2015) reported that three significant QTLs associated with resistance to RKN were mapped on Chrs. 10, 13, and 17, and also two QTLs associated with resistance to RN were detected on Chrs. 11 and 18 form PI 567516C. For RKN resistance, Luzzi et al. (1987) identified partial resistance in cultivar Forest (Luzzi et al. 1994). Recently, Pham et al. (2013) identified four candidate genes on Chr. 10 that carry a high level of resistance to RKN from PI96354 previously identified as having a high level of resistance to RKN. Three QTLs underlying RKN resistance in PI438489B, were identified on Chrs. 8, 10, and 13 (Xu et al. 2013).

Ibrahim et al. (2011) identified that silencing of tyrosine phosphatase (TP) and mitochondrial stress-70 protein precursor (MSP) genes can decrease gall formation of RKN. Charlton et al. (2010) mentioned that suppression of dual oxidase and a subunit of a signal peptidase reduced RKN numbers in roots. For RN resistance, six soybean lines, PI656647, PI659348, PI567516C, DS97-84-1, 02011-126-1-1-2-1, and 02011-126-1-1-5-1 were identified as having resistance to RN (Stetina et al. 2014). Melo et al. (2013) evaluated 199 genotypes for RN resistance. Among them Custer, PI437654, Fayette, BRSGO Ipameri, BRSMT Pintado, and BRS262 showed high levels of resistance to RN. Asmus (2008) evaluated 31 soybean genotypes for resistance to RN. Among them BRSMG250, TMG115RR, TMG121RR, MGBR015849, TMG113RR, BRS Jiripoca, and M-SOY833RR were not significantly different from the resistant cultivar 'Custer' (Rebois et al. 1970). Cardoso et al. (2014) reported that soybean resistance to RN is inherited quantitatively based on lines evaluated from two populations of Forrest (resistant) x BR96-25619 (susceptible) and Custer (resistance) x BR96-25619 (susceptible) normal distribution from highly resistant to highly susceptible. Ha et al. (2007) identified three QTLs conditioning RN resistant on Chrs. 11, 18, and 19 that explained 16, 8, and $21 \%$ of phenotypic variation, respectively from accession PI437654. This PI was also reported to be resistant to all known SCN HG Types and several resistance QTLs have been mapped from this source (Concibido et al. 2004). Iatsenko et al. (2014) reported that Bacillus thuringiensis DB27 produces two protoxins, Cry21Fa1 and Cry21Ha1, which act synergistically against nematodes.

Studham et al. (2009) conducted a study to identify whether Rag1, a single dominant gene for aphid resistance 
also confers resistance to both SCN and RKN similar to $\mathrm{Mi}-1.2$, a tomato gene that confers resistance to both aphid and RKN. They reported that the gene Rag1 does not confer resistance to SCN and RKN. Davis et al. (1998) identified N87539 and N91245 from the breeding program in North Carolina and G801515, G83559, G939106, and G939223 from the University of Georgia with resistance to both SCN and RKN. Kruger et al. (2008) reported that LS94-3207 and LNX97164-35-5 were resistant to SCN and RKN. Youssef et al. (2013) identified expression of cloned AtPAD4 (Phytoalexin-deficient4) gene in soybean roots, showing broadened resistance to SCN and RKN. Two soybean genotypes, Jake (PI643912) and S99-2281 developed by the University of Missouri Agricultural Experiment Station showed broad resistance to three nematode species, SCN, RKN, and RN (Shannon et al. 2007, 2009).

Kim et al. (2011) reported that stacking SCN resistance alleles of two QTL regions, $c q S C N-006$ and $c q S C N-007$, significantly increased resistance level compared to each allele separately. Thus, stacking resistance genes or QTL could result in high levels of resistance to SCN. Meksem et al. (2001) identified and mapped two genomic regions of rhg1 and Rhg4 that together explained over $98 \%$ of the phenotypic variation associated with resistance to SCN race 3 (HG Type 0 ).

The identification of new genetic sources with broad spectrum resistance to multiple SCN HG types, RKN and $\mathrm{RN}$ would be beneficial for the development of germplasm and varieties to reduce losses from these nematode species. In this study, 24 accessions were identified as sources of resistance to three nematode species in soybeans. Some of the resistance accessions to the three nematode species or were studied to understand genetics of nematode resistance. However, many of these sources have not been studied for inheritance of resistance to these different nematode species. These sources may possess unique and previously unidentified resistance genes that could be incorporated into new varieties with higher levels of resistance. This information will be useful to soybean breeders and other researchers who want to study genotypes or develop soybean cultivars with cross resistance to multiple nematodes species.

\section{REFERENCES}

Anand SC. 1992. Registration of 'Hartwig' soybean. Crop Sci. 32: 1069-1070.

Anand SC, Newman T, Fisher J. 2001. Registration of ‘Anand' Soybean. Crop Sci. 41: 919-920.

Asmus GL. 2008. Reaction of soybean genotypes to the reniform nematode. Trop. Plant Pathol. 33: 69-71.

Boerma HR, Hussey RS, Phillips DV, Wood ED, Finnerty SL. 1991. Registration of 'Bryan' soybean. Crop Sci. 31: 487.

Bradley EB, Duffy M. 1982. The value of plant resistance to soybean cyst nematode: A case study of Forrest soybeans. Report No. AGES820929. Natural Resources Economic Division, United States Department of Agriculture.

Buss GR, Camper Jr. HM, Roane CW. 1998. Registration of 'Hutcheson' soybean. Crop Sci. 28: 1024.

Cardoso PC, Asmus GL, Goncalves MC, Arias CAA, Carneiro GES. 2014. Inheritance of soybean resistance to Rotylenchulus reniformis. Trop. Plant Pathol. 39: 251-258.

Charlton WL, Hare HYM, Bakhetia M, Hibbard JK, Atkinson HJ, McPherson MJ. 2010. Additive effects of plant expressed double-stranded RNAs on root-knot nematode development. Int. J. Parasitol. 40: 855-864.

Concibido VC, Diers BW, Arelli PR. 2004. A decade of QTL mapping for cyst nematode resistance in soybean. Crop Sci. 44: 1121-1131.

Davis EL, Koenning SR, Burton JW, Barker KR. 1996. Greenhouse evaluation of selected soybean germplasm for resistance to North Carolina populations of Heterodera glycines, Rotylenchulus reniformis, and Meloidogyne species. J. Nematol. 28: 590-598.

Davis EL, Meyers DM, Burton JW, Barker KR. 1998. Resistance to root-not, reniform, and soybean cyst nematodes in selected soybean breeding lines. J. Nematol. 30: 530-541.

Faghihi J, Vierling RA, Halbrendt JM, Ferris VR, Ferris JM. 1995. Resistance genes in a 'Williams 82' x 'Hartwig' soybean cross to an inbred line of Heterodera glycines. J. Nematol. 27: 418-421.

Fehr WR, Caviness CE. 1977. Stages of soybean development. Iowa Agriculture Experiment Station Special Report 80.

Goswami BK, Agrawal DK. 1978. Interrelationships between species of Fusarium and root-knot nematode, Meloidogyne incognita, in soybean. Nematol. Mediterr. 6: 


\section{5-128.}

Greg RK, Xing L, Leroy AR, Westphal A. 2008. Meloidogyne incognita resistance in soybean under Midwest conditions. Crop Sci. 48: 716-726.

Ha BK, Robbins RT, Han F, Hussey RS, Soper JF, Boerma HR. 2007. SSR mapping and confirmation of soybean QTL from PI 437654 conditioning resistance to reniform nematode. Crop Sci. 47: 1336-1343.

Hartwig EE , Epps JM. 1973. Registration of Forrest Soybean. Crop Sci. 13: 287.

Iatsenko I, Boichenko I, Sommer RJ. 2014. Bacillus thuringiensis DB27 produces two novel protoxins, Cry21Fa1 and Cry21Ha1, which act synergistically against nematodes. J. Appl. Environ. Microbiol. 80: 3266-3275.

Ibrahim HM, Hosseini P, Alkharouf NW, Hussein EHA, Kader AE, Din YGE, Aly MAM, Matthews BF. 2011. Analysis of gene expression in soybean (Glycine max) roots in response to the root knot nematode Meloidogyne incognita using microarrays and KEGG pathways. BMC Genomics. 12: 220.

Jiao Y, Vuong TD, Liu Y, Li Z, Noe J, Robbins RT, Joshi T, Xu D, Shannon JG, Nugyen HT. 2015. Identification of quantitative trait loci underlying resistance to southern root-knot and reniform nematodes in soybean accession PI 567516C. Mol. Breed. 35: 131.

Kim MS, Hyten DL, Niblack TL, Diers BW. 2011. Stacking resistance alleles from wild and domestic soybean sources improves soybean cyst nematode resistance. Crop Sci. 51: 934-943.

Klink VP, Matthews BF. 2009. Emerging approaches to broaden resistance of soybean to soybean cyst nematode as supported by gene expression studies. Plant Physiol. 151: 1017-1022.

Kruger GR, Xing L, Leroy AR, Westphal A. 2008. Meloidogyne incognita resistance in soybean under Midwest conditions. Crop Sci. 48: 716-726.

Luzzi BM, Boerma HR, Hussey RS. 1987. Resistance to three species of root-knot nematode in soybean. Crop Sci. 27: 258-262.

Luzzi BM, Boerma HR, Hussey RS. 1994. A gene for resistance to the southern root-knot nematode in soybean. J. Heredity. 85: 484-486.

Luzzi BM, Boerma HR, Hussey RS, Phillips DV, Tamulonis J, Finnerty SL, Wood ED. 1997. Registration of Javanese root-knot nematode resistant soybean germplasm line
G93-9223. Crop Sci. 37: 1035-1036.

Meksem K, Pantazopoulos P, Njiti VN, Hyten DL, Arelli PR, Lightfoot DA. 2001. 'Forrest' resistance to the soybean cyst nematode is bigenic: saturation mapping of the Rhg1 and Rhg4 loci. Theor. Appl. Genet. 103: 710-717.

Melo CLP, Santos WRD, Asmus GL. 2013. Resistance of soybean genotypes to the reniform nematode in a controlled environment. Crop Breed. Appl. Biotechnol. 13: 23-32.

Niblack TL, Tylka GL, Riggs RD. 2004. Nematode pathogens of soybean, p. 821-851. In: H.R. Boerma and J.E. Specht (ed.). Soybeans: Improvement, production, and uses. 3rd ed. Agron. Monogr. 16. ASA, CSSA, and SSSA, Madison, WI.

Pantalone VR, Allen FL, Landau-ellis D. 2003. Registration of '5601T' soybean. Crop Sci. 43: 1123-1124.

Pham AT, MaNally K, Abdel-Haleem H, Boerma HR, Li Z. 2013. Fine mapping and identification of candidate genes controlling the resistance to southern root-knot nematode in PI 96354. Theor. Appl. Genet. 126: 1825-1838.

Rao-Arelli AP. 1994. Inheritance of resistance to Heterodera glycines race 3 in soybean accessions. Plant Disease. 78: 898-900.

Rebois RV, Epps JM, Hartwig EE. 1970. Correlation of resistance in soybeans to Heterodera glycines and Rotylenchulus reniformis. Phytopathology 60: 695-700.

Robbins RT, Rakes L, Elkins CR. 1994a. Reniform nematode reproduction and soybean yield of four soybean cultivars in Arkansas. Nematol. 26: 656-658.

Robbins RT, Rakes L, Elkins CR. 1994b. Reproduction of the reniform nematode on thirty soybean cultivars. J. Nematol. 26: 659-664.

Robbins RT, Rakes L. 1996. Resistance to the reniform nematode in selected soybean cultivars and germplasm lines. J. Nematol. 28: 612-615.

Robbins RT, Rakes L, Jackson LE, Dombek DG. 1999. Reniform nematode resistance in selected soybean cultivars. J. Nematol. 31: 667-677

Robbins RT, Rakes L, Jackson LE, Gbur EE, Dombek DG, Chen P, Shipe E, Shannon G. 2006. Reniform nematode reproduction on soybean cultivars and breeding lines in 2005 tests. Proc. of the 2006 Beltwide Cotton Conferences, 3-6 January 2006, San Antonio, TX, USA. pp. 46-59.

SAS Institute. 2004. SAS 9.1 user’s guide. SAS Inst., Gary, NC. 
Schmitt DP, Barker KR. 1988. Incidence of plant-parasitic nematodes in the coastal plain of North Carolina. Plant Disease 72: 107-110.

Shannon, JG, Arelli PR, Young LD. 2004. Breeding for resistance and tolerance, p. 155-180. In: D.P Schmitt, J.A. Wrather, and R.D. Riggs (ed.). Biology and management of soybean cyst nematode 2nd ed. Walsworth Publishing Company, Marceline, MO.

Shannon JG, Wrather JA, Sleper DA, Robbins RT, Nguyen HT, Anand SC. 2007. Registration of 'Jake' soybean. Crop Sci. 1: 29-30.

Shannon JG, Lee JD, Wrather JA, Sleper DA, Mian MAR, Bond JP, Robbins RT. 2009. Registration of S99-2281 soybean germplasm line with resistance to frogeye leaf spot and three nematode species. Crop Sci. 3: 94-98.

Stetina SR, McGawley EC, Russin JS. 1997. Relationship between Meloidogyne incognita and Rotylenchulus reniformis as influenced by soybean genotype. J. Nematol. 29: 395-403.

Stetina SR, Smith JR, Ray JD. 2014. Identification of Rotylenchulus reniformis resistant Glycine Lines. J. Nematol. 46: 1-7.

Studham M, MacIntosh GC, Avendaño F, Soh D, Tylka GL. 2009. The soybean resistance gene Rag1 does not protect against soybean cyst and root-knot nematodes. Plant Health Progress. doi: 10.1094/PHP-2009-0401-01-BR.

Vierling RA, Faghihi J, Ferris VR, Ferris JM. 1996. Association of RFLP markers conferring broad-based resistance to the soybean cyst nematode (Heterodera glycines). Theor. Appl. Genet. 92: 83-86.

Vuong TD, Sleper DA, Shannon JG, Nguyen HT. 2010. Novel quantitative trait loci for broad-based resistance to soybean cyst nematode (Heterodera glycines Ichinohe) in soybean PI 567516C. Theor. Appl. Genet. 121: 1253-
1266.

Vuong TD, Sleper DA, Shannon JG, Wu X, Nguyen HT. 2011. Confirmation of quantitative trait loci for resistance to multiple-HG types of soybean cyst nematode (Heterodera glycines Ichinohe). Euphytica. 181: 101-113.

Williams C, Gilman DF, Fontenot SD, Birchfield W. 1981. Inheritance of reaction to the reniform nematode in soybean. Crop Sci. 21: 93-94.

Wrather JA, Koenning SR, Anderson TR. 2003. Effects of diseases on soybean yield in the United States and Ontario (1999 to 2002). Plant Health Progress. doi: 10.1094/PHP-2003-0325-01-RV.

Wrather JA, Koenning SR. 2009. Effects of diseases on soybean yields in the United States 1996 to 2007. Plant Health Prog doi: 10.1094/PHP-2009-0401-01-RS.

Wrather JA, Koenning SR. 2010. Suppression of soybean yield potential in the continental United States by plant diseases from 2006 to 2009. Plant Health Progress doi: 10.1094/PHP-2010-1122-01-RS.

Wu X, Blake S, Sleper DA, Shannon JG, Cregan PB, Nguyen HT. 2009. QTL, additive, and epistatic effects for SCN resistance in PI 437654. Theor. Appl. Genet. 118: 10931105.

Xu X, Zeng L, Tao Y, Vuong T, Wan J, Boerma R, Noe J, Li Z, Finnerty S, Pathan SM, Shannon JG, Nguyen HT. 2013. Pinpointing genes underlying the quantitative trait loci for root-knot nematode resistance in palaeopolyploid soybean by whole genome resequencing. Proc. Natl. Acad. Sci. USA. 110: 13469-13474.

Youssef RM, MacDonald MH, Brewer EP, Bauchan GR, Kim KH, Matthews BF. 2013. Ectopic expression of AtPAD4 broadens resistance of soybean to soybean cyst and root-knot nematodes. BMC Plant Biol. 13: 67. 